\title{
Russernes drømme. Om det nye Russlands selvforståelse - og Vestens misforståelser
}

\author{
Vibeke Sperling \\ København: Gyldendal 2015 \\ 271 sider. ISBN 9788702170870
}

Anmeldt av Kirsti Stuvøy [PhD, førsteamanuensis, Norges miljø- og biovitenskapelige universitet, kirsti.stuvoy@nmbu.no]

I forholdet mellom Russland og Vesten ser mange i dag konturene av en ny kald krig. Dette avviser Vibeke Sperling i sin siste bok Russernes drømme. Etter hennes vurdering har vi å gjøre med en konfrontasjon om hvordan verden reelt ser ut (s. 254). I mange diskusjoner om russisk politisk utvikling i dag rettes blikket mot Kreml og den enorme oppslutningen om Putin, hvordan kan det ha seg at befolkningens støtte er så stor? Fra Sperlings ståsted ledes Russland av en «skidknægt» folket kanskje har valgt, men ikke «fortjent».

Demonstrasjonene i 2011 og 2012 ga også bud om mulig fallende oppslutning og i Kreml innså man et behov for å gjøre noe: «Dette noget blev at give russerne en for dem særlig attraktiv del af det tabte tilbake: Krim» (s. 16). Det har fungert etter hensikten, slår Sperling fast og forklarer på denne måten annekteringen av Krim som en reaksjon på en redsel for tap av makt og selvfølelse. I Sperlings bok er makt og identitet en rød tråd. Hun innleder med å si at Putin, som vanligvis har en hovedrolle i framstillinger av Russland i Vesten, ikke har det i hennes bok. Isteden skal Putin behandles som «et symbol på den postsovjetiske identitet - og et biprodukt av den» (s. 9). Jeg oppfatter dette som et forsøk på å ta avstand fra - eller et ønske om å komplementere - ensidige, Putin-sentrerte og maktorienterte forklaringer på utviklingen i Russland. Hvordan lykkes Sperling med det? Hvordan vektlegges identitet og maktpolitikk på en og samme tid i denne boka? Og hvilket bidrag gir det til debatten om å forstå Russland, slik Sperling setter seg som mål?

Boka er satt sammen av en innledning med tittelen «Balladen om Krim og Ukraina», og to hoveddeler. Første hoveddel er kalt «Russisk identitet og forhold til Europa og NATO» og den andre «Russlands venner og framtidsutsigter». Boka avsluttes med en epilog kalt «Det andet Russland».

I bokas første del får vi lese om Russlands forhold til Europa og NATOs østutvidelse, den antiliberale politikken fra Kreml de siste årene, om Putin som person, og om framveksten av retorikken om Novorossija. Dette er en tematisk bredde som gir god innsikt i ulike sider av det postsovjetiske Russland. Blant annet lykkes Sperling med å få fram sammenvevingen mellom nasjonal og global politisk utvikling, derunder hvordan antiliberale trekk i det russiske styresettet står i sammenheng med globale 
konservative krefter. President Putin framstår som den globale konservatismens leder, en rolle han utøver blant annet på møter i Valdai-diskusjonsklubben. Sperling trekker slik fram en møteplass som ikke nødvendigvis er like godt kjent i norsk/europeisk/ vestlig offentlighet, men som kan komme til å bli mer sentral for ideer om framtidige internasjonale politiske institusjoner som vi vil diskutere i årene som kommer. Sperling peker på at forsøket på å skape Russland som sentrum for global konservatisme også er med på å styrke landets utenforskap i internasjonal politikk.

Den første delen avsluttes med et kapittel om krisene som har preget Putins regjeringstid; katastrofen med ubåten Kursk som forliste i Barentshavet bare måneder etter han tiltrådte, gisseldramaet i Dubrovka-teateret i 2002 og Beslantragedien i 2004. Håndteringen av disse krisene har vært like hard og brutal som krigføringen i Tsjetsjenia. Konsekvensen er, skriver Sperling, en brutalisering av det russiske samfunnet (s. 115).

Et dagsaktuelt fokus kommer blant annet fram i vektleggingen av Novorossija, det separatistkontrollerte, russiskvennlige området i Øst-Ukraina. Novorossija er et viktig symbol på russisk politisk innblanding i Ukraina. Å forhindre en stabil (og dermed sterk) ukrainsk stat kan være formålet. Det er interessant at Sperling trekker fram forsker (nå leder) ved Carnegie-senteret i Moskva, Dmitri Trenin, som kilde til diskusjoner om å etablere et pro-russisk Novorossija etter orangerevolusjonen i 2003. Bare synd kildehenvisningen mangler. Det er ikke en konsekvent bruk av kildehenvisninger ved sitat i denne boka og det er ikke godt nok. Spørsmål om «sannhet» i vurderinger av dagens politiske utvikling i Russland er sentrale og krever etterrettelighet.

Det som er særlig interessant med Sperlings drøfting av Novorossijas betydning i russisk politikk er at hun trekker linjer til andre typer separatisme. Russland krever offisielt føderalisering av Ukraina; samtidig har styresmaktene i Russland slått hardt ned på krav om økt føderalisering/desentralisering. Sperling legger vekt på at den økende sentraliseringen i russisk politikk, parallelt med overføring av ansvar for sosialpolitikk til regionene, vil kunne føre til større spenninger og konflikter om føderalismens innhold i Russland. Det er jeg helt enig i, og Sperling ville gjort en bedre journalistisk jobb om hun hadde fått noen regionale aktørers synspunkt nettopp på disse utviklingstrekkene (og ikke holdt seg til én Moskva-basert journalist).

I andre hoveddel, «Russlands venner og fremtidsutsigter», dekkes forholdet til tidligere sovjetstater og utviklingen av den eurasiske union, samt utviklingen i relasjonene til India, Kina, Latin-Amerika, Midtøsten og Vesten. Russlands politikk overfor Ukraina, men også i Georgia i 2008, beskrives som nyimperialistisk. Russland har forsøkt å kombinere hard maktbruk i disse konfliktene med en «fredsmeglerrolle» i Nagorno-Karabakh, uten å lykkes i særlig grad. Det framstår som et strategisk alternativ for Russland å la «fastfrosne» konflikter prege sin yttergrense. Sperling argumenterer for at denne «kampen om det postsovjetiske rom» vil fortsette uten regler hvis ikke Russland og Vesten tvinges til samarbeid. Det siste ser hun som usannsynlig, dog ønskelig, blant annet fordi slike konflikter kan være en sikkerhetsrisiko for hele Europa. 


\section{4 | KIRSTI STUVØY}

Slik Sperling ser det er det et hovedmål for Kreml å fange tidligere sovjetrepublikker inn i Moskva-dominerte styringsstrukturer. Denne maktpolitiske interessen ligger til grunn for Den eurasiske union. Økonomisk vil dette kunne bli et tapsprosjekt for Moskva, men det kan, slik Sperling forklarer, gis mening i en oss-mot-dem-tankegang: Den eurasiske union er vendt mot vestlig innflytelse. Økt vestlig innflytelse i denne regionen vil være et tap for Russland. Det mest interessante er imidlertid hvordan disse rasjonalitetene virker sammen; hva gjør russiske styresmakter når det blir enda klarere for befolkningen at de økonomiske belastningene for elitens imperialistiske prosjekt, bæres av dem? Er hatet mot Vesten slik i den russiske befolkningen, at de vil støtte det uansett? Er det russernes drøm å kontrollere tidligere sovjetrepublikker? Sperling stiller ikke slike spørsmål, og dét er litt underlig i lys av bokas tittel: «Russernes drømme». Samtidig er svarene rimelig åpenbare, for selvsagt drømmer ikke russere flest om verken den ene eller andre av disse politiske forestillingene. Det underlige i Sperlings analyse er at hun tar til orde for å ikke rette all oppmerksomhet mot Putin og elitene, men ender opp med å gjøre nettopp det.

Til slutt, i epilogen, står det dagsaktuelle i fokus. Sperling forteller om drapet på Boris Nemtsov i februar 2015 og setter dette i sammenheng med økte politiske motsetninger og protester innad i Russland. Dette er «det andre Russland» og forandringer vil vokse fram, dog med store vanskeligheter: det er få ungdommer og dermed mindre sannsynlig med et ungdomsopprør; middelklassen er utrolig utholdende, og russere flest har liten tro på enkeltindividets muligheter til å bidra til endring. Samtidig peker Sperling på at krigen i Ukraina går imot den russiske befolkningen også fordi den stadig får sine menneskerettigheter krenket. Dette er en påminnelse om at det å undersøke disse «russernes drømme», eller politiske forestillinger, er interessant. Den boka har Sperling fortsatt ikke skrevet, til tross for tittelen og en innholdsrik, tematisk bred bok om makt og identitet i den politiske utviklingen i dagens Russland. 